\title{
Hydrogen and Oxygen Isotope Characteristics of Water and the Recharge Sources in Subalpine of Qilian Mountains, China
}

\author{
Yang Shi ${ }^{1}$, Wenxiong Jia ${ }^{1 *}$, Guofeng Zhu ${ }^{1,2}$, Dan Ding ${ }^{3}$, Ruifeng Yuan ${ }^{1}$, Xiuting Xu ${ }^{1}$, \\ Zhiyuan Zhang ${ }^{1}$, Le Yang ${ }^{1}$, Hui Xiong ${ }^{1}$ \\ ${ }^{1}$ College of Geography and Environmental Science, Northwest Normal University, Lanzhou, Gansu Province, China \\ ${ }^{2}$ State Key Laboratory of Cryosphere Science, Northwest Institute of Eco-Environment and Resources, \\ Chinese Academy of Sciences, Lanzhou, Gansu Province, China \\ ${ }^{3}$ College of Geography and Tourism, Shaanxi Normal University, Xi'an, Shaanxi Province, China
}

Received: 21 July 2020

Accepted: 25 September 2020

\begin{abstract}
In order to explore the characteristics of hydrogen-oxygen isotopes and ecological hydrological processes in different water bodies in the subalpine zone of Qilian Mountains, China, precipitation, soil water, plant water, groundwater and river water samples were collected from the subalpine of the Eastern of Qilian Mountains section from July to August in 2015. Qualitative analysis was used in hydrogen and oxygen isotope characteristics of different water bodies. Then, the mixing model of MixSIAR based on Bayesian theory was used to quantify the water absorption depth of shrub plant and the proportion of water source replenishment between different water bodies. The purpose is to illustrate the water migration relationship between water bodies, thereby to clarify the ecological hydrological process in the subalpine shrub area of Eastern Qilian Mountains. Results indicate that: (1) The isotopic values of various water bodies in the study area are affected by changes in the amount of precipitation, but precipitation has a smaller impact on river water. (2) Soil water of $0 \sim 20 \mathrm{~cm}$ is affected easily by precipitation and evaporation, while soil water of $60 \sim 80 \mathrm{~cm}$ is affected strongly by groundwater. (3) The water content of shrub plant in study area is mainly derived from precipitation and soil water under $0 \sim 20 \mathrm{~cm}$. (4) Although the direct influence on the values of $\delta^{18} \mathrm{O}$ in groundwater and river water by precipitation is not obvious and their variation ranges are small, there are different degrees of response to precipitation, and river water responds faster to precipitation than groundwater.
\end{abstract}

Keywords: Qilian Mountains, subalpine, hydrogen and oxygen isotope, MixSIAR model, water cycle

*e-mail: wxjiaxy@163.com 


\section{Introduction}

Mountain water resources and their changes are of great significance to the ecosystems in the arid regions of northwestern China. Accurate understanding on the water migration and circulation processes of various water bodies in mountainous areas is not only the fundamental issue of water research in cold and arid areas, but also the basis for carrying out fine management and regulation of water resources [1, 2]. Due to the response of hydrogen and oxygen isotopes to environmental changes and the mixing action between different water bodies, the composition of isotopes in different water bodies in nature is different and varies spatially [3]. Therefore, hydrogen and oxygen isotopes are useful tracers in water cycle research. It plays an important role in the study of the transformation process of water bodies, such as atmospheric precipitation, soil water, plant water, groundwater and river water [4-9]. The methods for estimating quantitatively the replenishment sources of different water bodies by using hydrogen-oxygen isotopes include mainly two or three-compartment linear mixing models [10], such as IsoSource mixing model [11], Bayesian-based MixSIR, SIAR and MixSIAR mixing models [12-14]. The mixing model of MixSIAR combines the advantages of the models of MixSIR and SIAR. Compared with the mixing model of IsoSource, it is more accurate in calculating the water source and contribution ratio of different water bodies [14]. At present, researches on isotope water sources based on MixSIAR model focus mainly on the analysis of water absorption source for crops [15-17] and the pollution sources of groundwater and surface water $[18,19]$. It has not been reported that the MixSIAR model is used to identify quantitatively the contribution ratio of different water sources in subalpine region.

Qilian Mountain is an important water supply area for the inland rivers of the Hexi Corridor. It is also a crucial ecological security barrier in the northwestern part of China. It not only inhibits the formation and expansion of sand sources in China, but also guarantees the stability and ecological security of corridor oases. Qilian Mountain utilizes effectively the water vapor conditions of westerly and monsoon and hosts diverse ecosystems such as forests, grasslands and alpine meadows [20]. Subalpine shrub is the main component of water conservation forest of Qilian Mountain, which is called "green reservoir". Its distribution area is about $4.13 \times 10^{3} \mathrm{~km}^{2}$, accounting for about $68 \%$ of the forestry land area in mountainous areas, and the effective storage capacity is above $3 \times 10^{8} \mathrm{~m}^{3}[21,22]$. To evaluate the sustainable use of water resources and ecological security, it is the key to clarify the mutual relationship and the conversion volume among various water bodies in the Qilian Mountains, especially the sources of plant moisture in subalpine shrub areas [23]. In recent years, scholars have focused on single types of water bodies such as precipitation and river water as well as the contribution and transformation between surface water and groundwater or soil water and groundwater [24-29]. Therefore, the study of the hydrological cycle in the subalpine region is still in its infancy. Using stable isotope techniques to explore the water sources of various water bodies, it is helpful to understand and grasp the mechanism of the hydrological cycle in this area, and is of great significance to protect the ecological environment of Qilian Mountain.

In this study, the hydrogen-oxygen isotopes characteristics of different water bodies in the subalpine shrub area of Qilian Mountains were studied. The MixSIAR model was used to study the recharge sources of each water body, and then analyze quantitatively the mutual transformation relationship between various water bodies. This will help to understand the hydrological cycle mechanism in the subalpine shrub area of Qilian Mountains, and has important theoretical and practical significance for the uptake of plant water, the recharge of groundwater, the rational utilization of soil water and groundwater resources, and the optimization of plant cover.

\section{Data and Methods}

Study Region

Fig. 1 shows that the study region is located in the subalpine shrub area of the upper reaches of Jinqiang River in the Eastern of Qilian Mountains $\left(37^{\circ} 10^{\prime} 19^{\prime \prime} \mathrm{N}\right.$, $102^{\circ} 47^{\prime} 25^{\prime \prime} \mathrm{E}$, altitude $\left.3009.3 \mathrm{~m}\right)$. The terrain is dominated by mountains and river valleys, which the western area is higher than the eastern area and the central part is flat. Formed by geological influences, the valley extends from west to east, and the gradient of river is large. The climate is a typical plateau continental climate with only cold season and warm season. The annual average temperature varies from $-0.1^{\circ} \mathrm{C}$ to $1.2^{\circ} \mathrm{C}$, and the extreme minimum temperature is $-34.9^{\circ} \mathrm{C}$ (in January), and the extreme maximum temperature is $28^{\circ} \mathrm{C}$ (in July) [30]. Caused by terrain, the annual rainfall is $418.8 \mathrm{~mm}$, and concentrates mainly on July to September. The annual evaporation is $1592 \mathrm{~mm}$, which is 3.8 times the precipitation amount [31]. The soil thickness of the sample area is about $40 \sim 80 \mathrm{~cm}$, and the content of organic matter is about $10 \% \sim 16 \%$, and the total porosity of the soil is $65.22 \% \sim 76.79 \%$ [32]. Plant cover types are dominated by alpine shrub meadows and alpine meadow grasslands [33].

\section{Sample Collection}

From July to August 2015, the samples of precipitation, soil water, plant water, groundwater and river water were systematically collected (Fig. 1). Precipitation samples were collected by a standard amount of rain gauge, which was placed at $1.5 \mathrm{~m}$ away from the ground and no obstacles around it. 


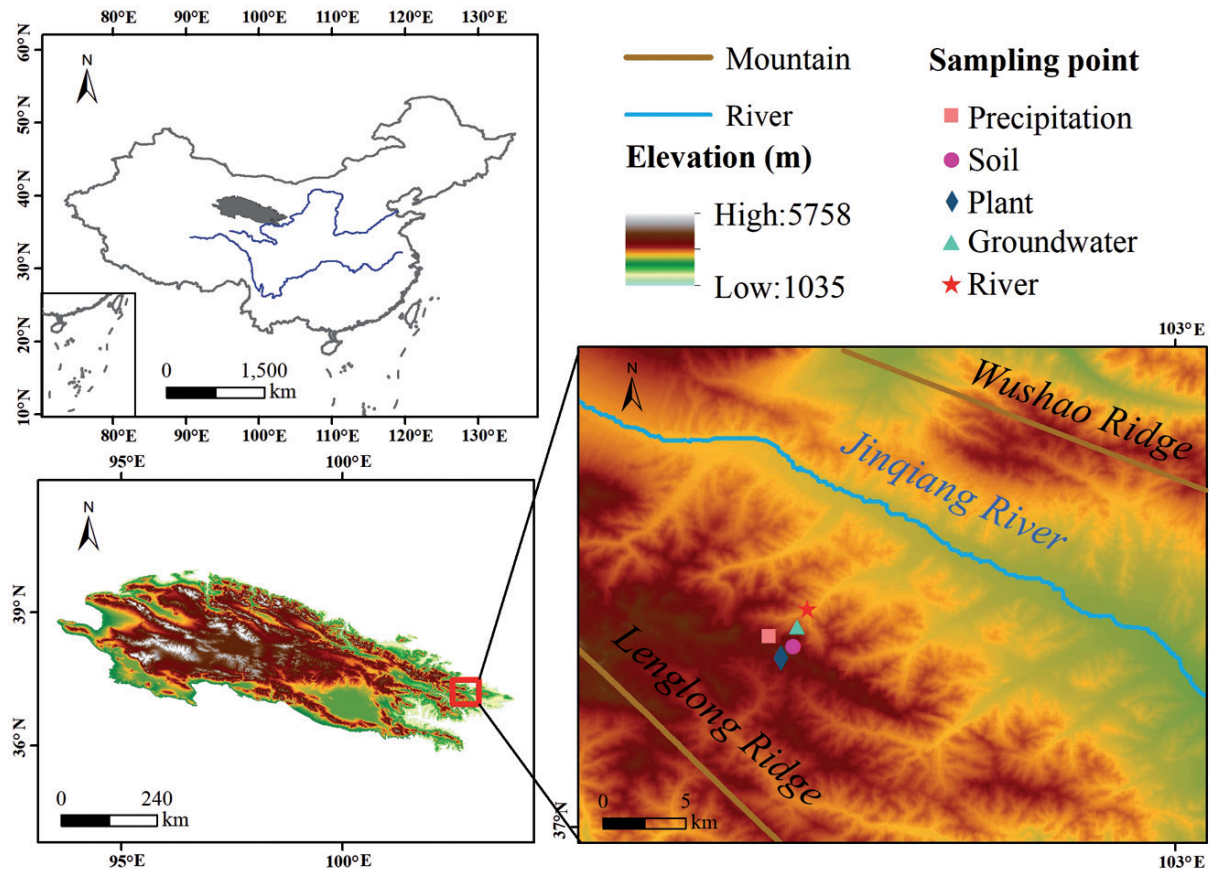

Fig. 1. Location of the study area and sampling points.

In addition, the mouth of the rain gauge was horizontal. After each precipitation event, the precipitation amount was recorded and the collected precipitation was poured into the sample bottle. The soil samples were collected by a soil drill with $1 \mathrm{~m}$ long. The sampling plots were selected at three locations with relatively uniform topography. The sampling depth was $80 \mathrm{~cm}$, and was separated by $10 \mathrm{~cm}$. Part of the soil samples were used to extract water, and the other samples were placed in aluminum boxes to determine the soil moisture content by drying method. Plant samples were selected from 6 typical dominant species such as Salix oritrepha Schneid, Salix cupularis, Rhododendron capitatum Maxim, Rhododendron thymifolium Maxim, Spiraea Salicifolia L. and Potentilla fruticosa Linn. 5 7 nongreen corked branches with a diameter of about $0.3 \mathrm{~cm}$ and a length of about $5 \mathrm{~cm}$ were cut on each plant with the same growth condition, and the rind and phloem were removed quickly, then load immediately into the sample bottles. Well water ( $8 \mathrm{~m}$ deep) about $60 \mathrm{~m}$ away from the soil and plant sampling points was collected as groundwater samples. The river water from the tributary of Jinqiang River about $150 \mathrm{~m}$ away from the soil and plant sampling points was collected as river water samples. In order to make the data accurate, the river water about $10 \mathrm{~cm}$ below the central water surface of the river was collected after washing 3 times, and put into sampling bottle. The water samples of groundwater and river were collected every two days from July $13^{\text {th }}$ to August $12^{\text {th }}$. All samples were filled into polyethylene bottles of $10 \mathrm{~mL}$, and sealed with sealing film called parafilm, and stored in cold storage (about $-15^{\circ} \mathrm{C}$ ). During the period of sample collection, a total of 104 samples were collected, including
11 precipitation samples, 40 soil samples, 21 plant samples, 16 groundwater samples and 16 river water samples (samples collected exactly at the same location).

\section{Sample Laboratory Determination}

Vacuum distillation is more suitable for soil and plant water extraction than azeotropic distillation, and the water extracted by vacuum distillation can reflect more accurately the composition of hydrogen and oxygen isotopes in the sample [34]. Therefore, the soil water and plant water were extracted by lowtemperature vacuum distillation (LI-2100 Automatic Water Extraction System). The $\delta^{2} \mathrm{H}$ and $\delta^{18} \mathrm{O}$ of each water body were measured by DLT-100 liquid water isotope analyzer (Los Gatos Research, Mountain View, USA). The measured data were given by the V-SMOW standard (Vienna Standard Mean Ocean Water):

$$
\delta^{18} O\left(\delta^{2} H\right)=\left(\frac{R_{\text {sample }}}{R_{V-S M O W}}-1\right) \times 1000 \%
$$

In Eq.(1), $\mathrm{R}_{\text {sample }}$ and $\mathrm{R}_{\mathrm{V}-\mathrm{Smow}}$ are the ratios of hydrogen or oxygen isotopes in water samples and the Vienna standard mean ocean water, respectively. The analytical precision of $\delta^{2} \mathrm{H}$ value is less than $\pm 0.6 \%$, and the analytical precision of $\delta^{18} \mathrm{O}$ value is less than $\pm 0.2 \%$. Spectral contamination correction was performed on the measured data by using LWIA-Spectral Contamination Identifier v1.0 software. All experiments were performed at the Hydrogenoxygen Isotope Laboratory of Northwest Normal University. 


\section{Research Methods}

The contribution from different water sources can be calculated by using the MixSIAR model based on Bayesian theory. It can estimate the contribution of each water source in the water body by defining the hydrogen and oxygen isotopes of multiple sources of water. The model runs in the open source software $\mathrm{R}$ and takes the effect of isotope fractionation into account. The input data of the MixSIAR model includes source data and mixture data. The isotope values of plant xylem water are input directly into the model, which need not to be processed. The discrimination values are set to 0 for plant water isotope, because the hydrogen-oxygen isotopes value of most plants generally does not change during plant water transportation in the xylem of plant stems, except for some coastal halophytes [35]. The Markov Chain Monte Carlo (MCMC) parameter is set to "very long" of run length. Since the water source of a single water body is greater than one, the model error is selected as "process+residual". The corresponding median (50\% quantiles) contribution ratio estimated for each water source is regarded as the contribution of the water source to the mixed water.

The soil layer needs to be divided before using Bayesian model analysis. According to the standard deviation and variation coefficient of $\delta^{18} \mathrm{O}$ values of soil water, the soil water is divided into 3 sections: surface layer $(0 \sim 20 \mathrm{~cm})$, middle layer $(20 \sim 60 \mathrm{~cm})$ and deep layer $(60 \sim 80 \mathrm{~cm})$. The isotope values of soil water corresponding to the layers are taken as the average of all sampling depths within the layer. The sampling plot position of river water is lower than that of the groundwater, so the river water can't be considered in the recharge of groundwater sources.

To be consistent to the sampling period of soil water and plant water, the precipitation of 12 day before that was taken as a possible water source, and the weighted average method was used to obtain the average values of the hydrogen and oxygen isotope in precipitation.

$$
\overline{\delta X}=\sum P_{\mathrm{i}} \delta X_{\mathrm{i}} / \sum P_{\mathrm{i}}
$$

In Eq.(2), $\delta \mathrm{X}$ and $\mathrm{Pi}$ are the ${ }^{2} \mathrm{H}\left({ }^{18} \mathrm{O}\right)$ values and the corresponding precipitations, respectively.

To analyze the characteristics of each water bodies, statistical analysis and linear regression analysis of $\delta^{2} \mathrm{H}$ and $\delta^{18} \mathrm{O}$ were performed by using Origin 2018. In addition, the trace of water vapor source in precipitation was analyzed by the data of NOAA atmospheric reanalysis and the HYSPLIT model.

\section{Results}

\section{Relationship between $\delta^{2} \mathrm{H}$ and $\delta^{18} \mathrm{O}$ of Various Water Bodies}

The sample measurement results are shown in Table 1. From the statistical results, the $\delta^{2} \mathrm{H}$ and $\delta^{18} \mathrm{O}$ values of different water bodies have obvious differences. The isotope value of precipitation is the highest and its fluctuation range is the largest. The isotope values and variation ranges of plant water and soil water are less than that of precipitation. The isotope values and variation ranges of river water and groundwater are relatively smaller among 5 water bodies, indicating that groundwater and river water are relatively stable.

Established by the isotope values of precipitation from July to August, the local meteoric water line (LMWL) in the study area is $\delta^{2} \mathrm{H}=7.7758 \delta^{18} \mathrm{O}+12.3417$ $\left(\mathrm{R}^{2}=0.8719, \mathrm{n}=11\right)$ (Fig. 2). Comparing the LMWL in the Wushaoling calculated by $\mathrm{Li}$ et al. [24] $\left(\delta^{2} \mathrm{H}=7.22 \delta^{18} \mathrm{O}+9.13\right)$ and $\mathrm{Xu}$ et al. [36] $\left(\delta^{2} \mathrm{H}=7.77 \delta^{18} \mathrm{O}+16.73\right)$ for a longer period, it can be seen that the LMWL in summer is relatively consistent

Table 1. Hydrogen and oxygen isotope ratio in different water bodies.

\begin{tabular}{|c|c|c|c|c|c|}
\hline & Different water bodies & Number & Range (\%o) & Average value (\%o) & Standard deviation \\
\hline \multirow{5}{*}{$\boldsymbol{\delta}^{2} \mathrm{H}$} & Precipitation & 11 & $-49.06 \sim 9.63$ & -17.34 & 19.37 \\
\hline & Soil water & 24 & $-57.67 \sim-35.49$ & -47.10 & 5.55 \\
\hline & Plant water & 18 & $-51.75 \sim-32.63$ & -43.89 & 4.52 \\
\hline & Groundwater & 16 & $-56.33 \sim-53.27$ & -54.63 & 0.84 \\
\hline & River water & 16 & $-54.99 \sim-49.76$ & -52.50 & 1.39 \\
\hline \multirow{5}{*}{$\boldsymbol{\delta}^{18} \mathrm{O}$} & Precipitation & 11 & $-8.26 \sim-0.76$ & -3.97 & 2.33 \\
\hline & Soil water & 24 & $-9.06 \sim-4.98$ & -7.55 & 0.91 \\
\hline & Plant water & 18 & $-6.33 \sim-4.04$ & -5.44 & 0.68 \\
\hline & Groundwater & 16 & $-9.32 \sim-8.53$ & -8.91 & 0.21 \\
\hline & River water & 16 & $-8.96 \sim-8.46$ & -8.79 & 0.15 \\
\hline
\end{tabular}

Note: The average value of precipitation is the amount weighted average, and the "Number" is the number of valid samples. 


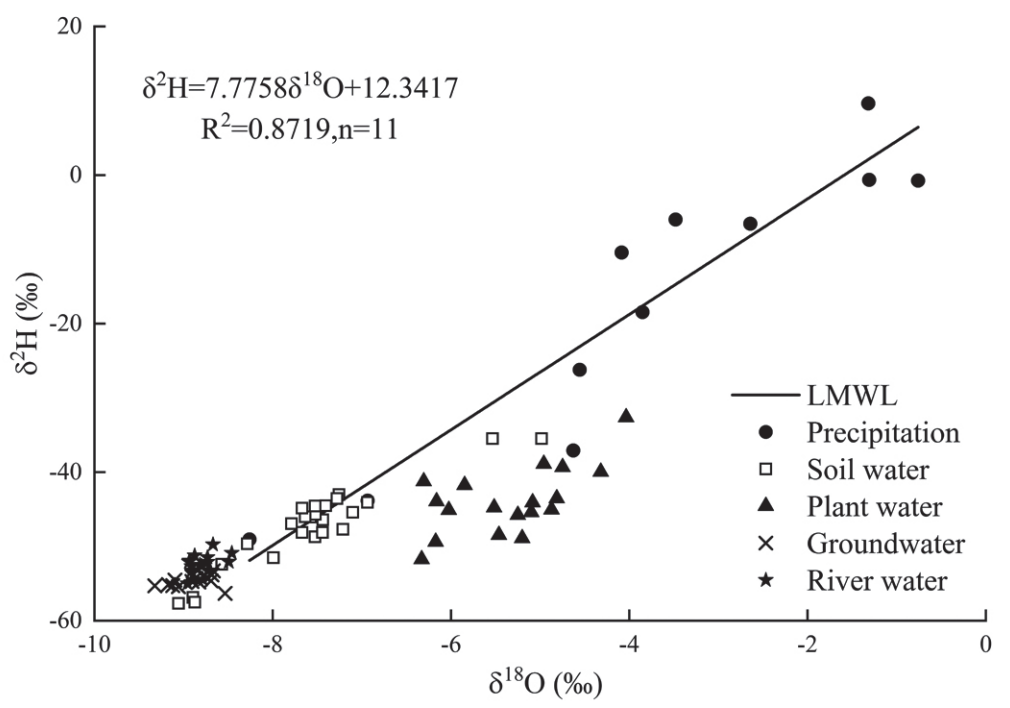

Fig. 2. Relationship between $\delta^{2} \mathrm{H}$ and $\delta^{18} \mathrm{O}$ in different water bodies.

with that of the longer-period except for the intercepts. This indicates the imbalance of evaporation in different periods in study area. Comparing the hydrogen and oxygen isotopes of groundwater, river water, soil water, and plant water with LMWL, it can be seen that points of river water and groundwater are located at the upper left of the LMWL, and are close to the atmospheric precipitation line. This indicates that precipitation has a replenishing effect on river water and groundwater [37]. Most points of plant water are located at the lower right of LMWL, which indicates that the isotope enrichment is obvious during the transpiration process of plant water. Except that a few points of soil water are far away from LMWL, the rest are distributed near the atmospheric precipitation line, which indicates that precipitation has a more obvious replenishment effect on soil water.

\section{The Hydrogen-Oxygen Isotopes Characteristics of Precipitation}

By comparing the isotopic values of different water bodies in study area from July to August, the $\delta^{2} \mathrm{H}$ and $\delta^{18} \mathrm{O}$ values in precipitation fluctuate widely. The variation range of $\delta^{2} \mathrm{H}$ is $-49.06 \%{ }^{\circ} \sim 9.63 \%$, the weighted average is $-17.34 \%$ and the standard deviation is 19.37 . The range of $\delta^{18} \mathrm{O}$ varies from $-8.26 \%$ o to $-0.76 \%$, the weighted average is $-3.97 \%$ and the standard deviation is 2.33. The $\delta^{18} \mathrm{O}$ values of precipitation during the sampling period in the study area are all within the range of China (-24\%o 2\%o) [38] and global (-50\%o 10\%o) [39]. Compared with the national average of $-8 \%$, the mean is higher, but the degree of depletion is not obvious. In addition, there is a significant negative correlation between the precipitation and the isotope value, that

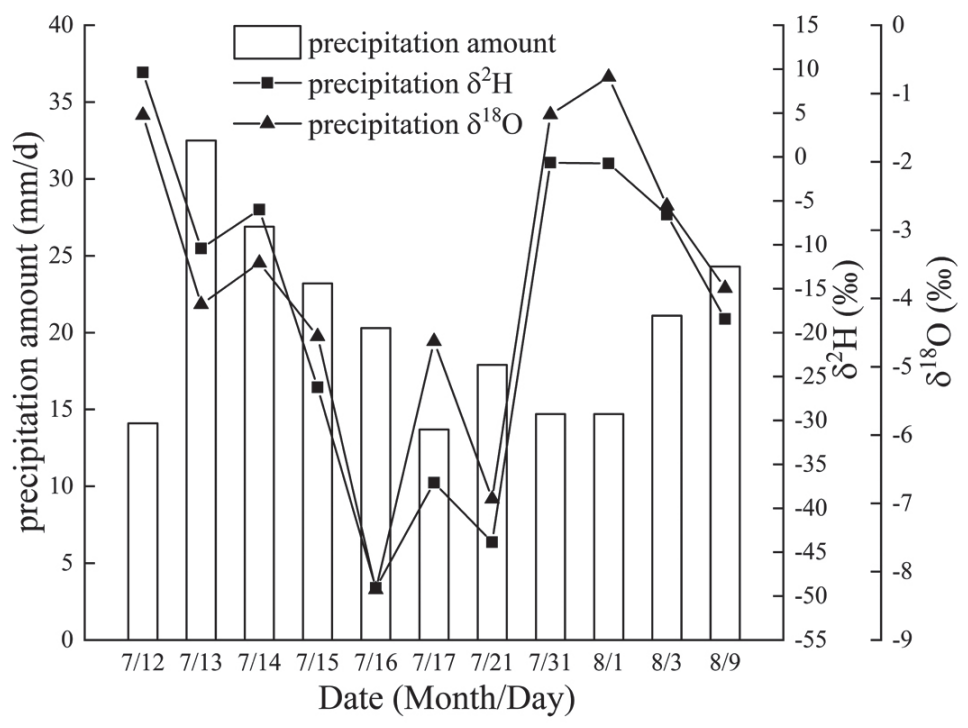

Fig. 3. Relationship between precipitation amount and $\delta^{2} \mathrm{H}\left(\delta^{18} \mathrm{O}\right)$ during sampling period. 
the low value appear in the wet period but the high value appear in the drying period (Fig. 3). According to the Rayleigh model, the precipitation amount is proportional to the degree of cooling, but the isotope value is inversely proportional to it, which in some cases causes the precipitation is inversely proportional to the isotope value [40]. The linear correlation between $\delta^{18} \mathrm{O}$ in precipitation and precipitation amount $(\mathrm{P})$ is as follow:

$$
\delta^{18} \mathrm{O}=-0.0985 \mathrm{P}-1.8021 \quad\left(\mathrm{R}^{2}=-0.2568, \mathrm{n}=11\right)
$$

It demonstrates that the $\delta^{18} \mathrm{O}$ change of the precipitation in study area has the effect of precipitation amount. This is consistent with the research result in the rainy season precipitation of alpine region in the upper reaches of the Heihe River, and also consistent with that in the short-term precipitation of the western mountainous areas in the Qinghai-Tibet Plateau [41, 42]. At the same time, it is worth noting that the change of precipitation amount is not the decisive factor for affecting the $\delta^{18} \mathrm{O}$ change of precipitation. It is mainly due to isotope fractionation caused by evaporation and condensation during water circulation [3]. For example, during the continuous precipitation period from July $12^{\text {th }}$ to $17^{\text {th }}$, the isotope values of precipitation continued to decline as a whole, which was related to the isotope depletion caused by the continuous condensation of water vapor. However, opposite to this downward trend, the isotope value shows an abnormal increase on July $14^{\text {th }}$ and July $17^{\text {th }}$, which may be related to the temperature. According to the data of Wushaoling meteorological station, the average temperatures on July $14^{\text {th }}$ and July $17^{\text {th }}$ were $13^{\circ} \mathrm{C}$ and $13.5^{\circ} \mathrm{C}$ respectively, which were $2 \sim 3^{\circ} \mathrm{C}$ higher than two days ago. This indicates that the abnormal increase of isotope values on these two days is due to the heavy isotope enrichment caused by higher temperature.

\section{The Hydrogen-Oxygen Isotopes Characteristics of Soil Water}

Soil water is an important part of the natural water cycle, which is the mixed water of precipitation and original soil water. The variation of hydrogen and oxygen isotope is affected by various factors, such as precipitation intensity, precipitation duration and soil characteristics [6]. The $\delta^{2} \mathrm{H}$ value of soil water varies from $-57.67 \%$ to $-35.49 \%$ (arithmetic mean $-47.10 \%$ ), the variation range is $22.18 \%$ and the standard deviation is 5.55. The $\delta^{18} \mathrm{O}$ value of soil water varies from $-9.06 \%$ to $-4.98 \%$ (arithmetic mean $-7.55 \%$ ), the variation range is $4.07 \%$ and the standard deviation is 0.91 . The $\delta^{18} \mathrm{O}$ value of soil water is relatively stable than $\delta^{2} \mathrm{H}$ value. Compared with the isotope values of precipitation, the isotope values of soil water are smaller and the magnitudes of change are as well.

Fig. 4 shows the variation characteristics of $\delta^{2} \mathrm{H}$ and $\delta^{18} \mathrm{O}$ of soil water from $0 \sim 80 \mathrm{~cm}$ during sampling period. It shows that the ratios of hydrogen and oxygen isotope of soil water in different soil layers have significant difference at different time periods. The change trend of $\delta^{2} \mathrm{H}$ and $\delta^{18} \mathrm{O}$ of soil water is relatively consistent, which follows the trend of "decreases-increasesdecreases". The values of $\delta^{2} \mathrm{H}$ and $\delta^{18} \mathrm{O}$ are very high in the range of $0 \sim 10 \mathrm{~cm}$, and the average values are $-38.35 \%$ and $-5.82 \%$, respectively. This is caused by the higher values of hydrogen and oxygen isotope of precipitation and the heavy isotopic enrichment of surface soil water for evaporation fractionation, which makes the values of hydrogen and oxygen isotope of surface soil water appear significantly positive [43]. The values of $\delta^{2} \mathrm{H}$ and $\delta^{18} \mathrm{O}$ at $10 \sim 20 \mathrm{~cm}$ decrease rapidly to $-47.12 \%$ and $-7.79 \%$, but they increase gradually and stabilized at $20 \sim 60 \mathrm{~cm}$, and the average values are $-46.49 \%$ and $-7.51 \%$, respectively. This indicates that precipitation replenishes to the soil layer at this depth
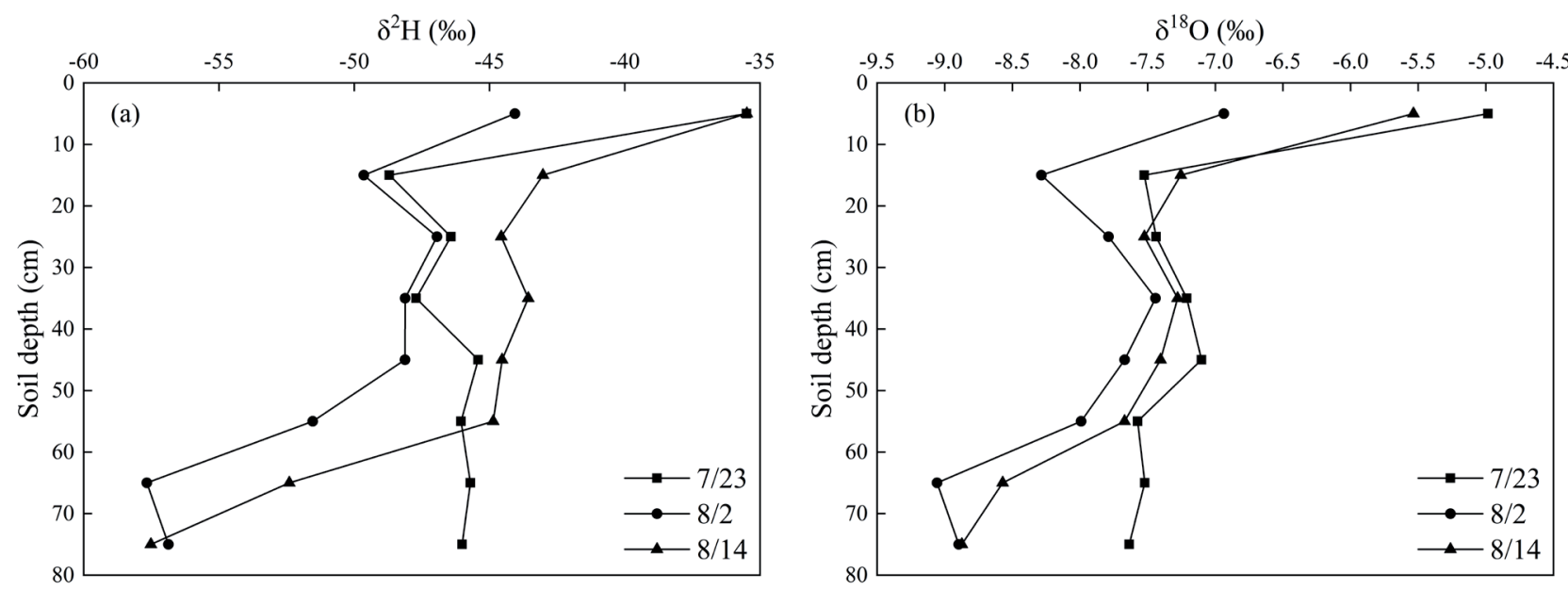

Fig. 4. Characteristics of $\delta^{2} \mathrm{H}$ and $\delta^{18} \mathrm{O}$ values of soil water at different depths in different periods. (a) $\delta^{2} \mathrm{H}$ value of soil water, (b) $\delta^{18} \mathrm{O}$ value of soil water. 


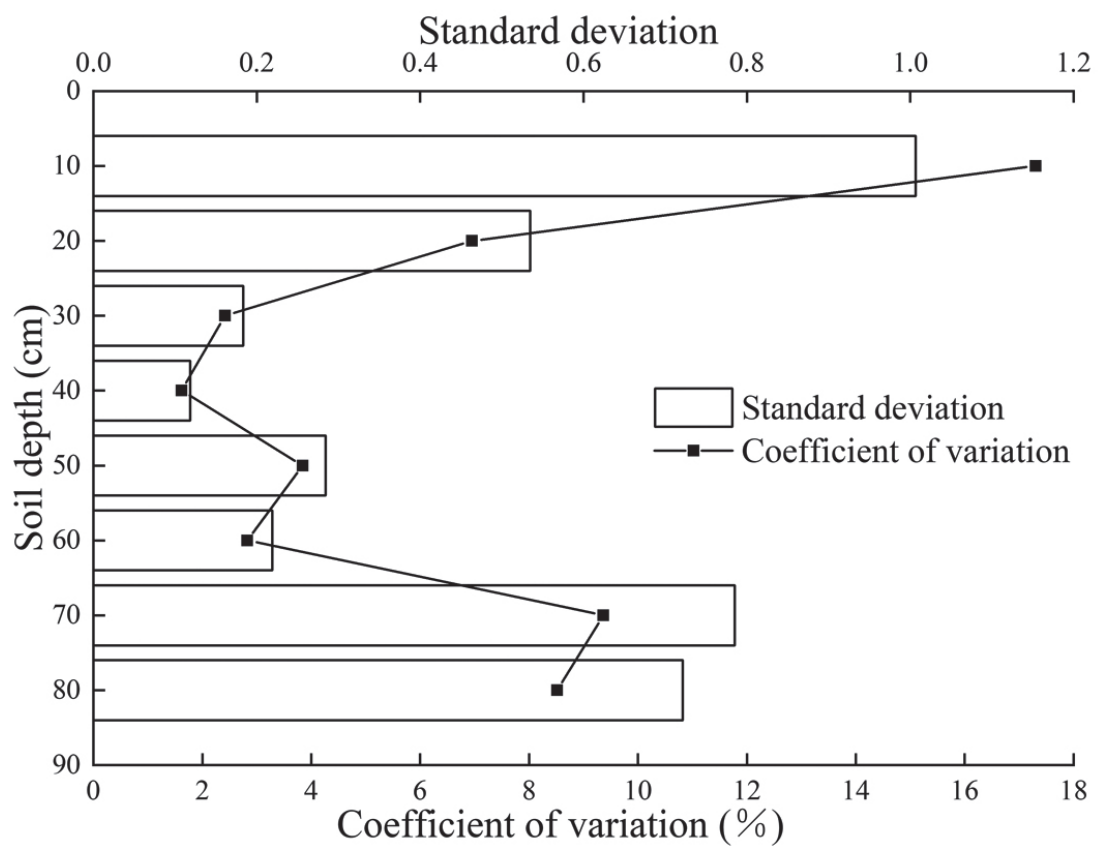

Fig. 5. Variation characteristics of standard deviation and variation coefficient of $\delta^{18} \mathrm{O}$ value of soil water with depth.

less than the surface layer. In addition, surface soil water and deep soil water have a better mixing effect at this depth, so the values of $\delta^{2} \mathrm{H}$ and $\delta^{18} \mathrm{O}$ are relatively stable. The values of $\delta^{2} \mathrm{H}$ and $\delta^{18} \mathrm{O}$ are the lowest at $60 \sim 80 \mathrm{~cm}$, and the average values are $-52.69 \%$ and $-8.43 \%$, respectively. This indicates that the soil layer below $60 \mathrm{~cm}$ is affected weakly by evaporation. On July $23^{\text {rd }}$, the overall fluctuations of $\delta^{2} \mathrm{H}$ and $\delta^{18} \mathrm{O}$ values of soil water were not large, indicating that the recharge ratio of precipitation and groundwater to soil water was relatively close. This indicates that the water source of soil water was stable. On August $14^{\text {th }}, \delta^{2} \mathrm{H}$ and $\delta^{18} \mathrm{O}$ of soil water did not increase but decrease in $20 \sim 30 \mathrm{~cm}$, which was caused by the decrease of precipitation amount in August and the isotope fractionation during the slow infiltration of early precipitation. On August $2^{\text {nd }}$ and August $14^{\text {th }}$, the values of $\delta^{2} \mathrm{H}$ and $\delta^{18} \mathrm{O}$ in deep soil water decreased rapidly and approached to the average values of them in groundwater, which shows that the groundwater plays a vital role in replenishing deep soil water during periods of low precipitation amount.

By comparing the standard deviation with variation coefficient of $\delta^{18} \mathrm{O}$ value of soil water at different depths (Fig. 5), it can be clearly seen that there is a significant difference in different soil depths during the sampling period. The standard deviation and variation coefficient of $\delta^{18} \mathrm{O}$ values of soil water in $0 \sim 20 \mathrm{~cm}$ and $60 \sim 80 \mathrm{~cm}$ are higher, indicating that soil water is active in these soil layers. This is because shallow soil water is affected easily by precipitation and evaporation, but deep soil water is affected easily by groundwater. The standard deviation and the variation coefficient of $\delta^{18} \mathrm{O}$ value of soil water in $20 \sim 60 \mathrm{~cm}$ are lower, which illustrates that soil water is relatively stable. The middle layer is not only less affected by precipitation and evaporation, but also less affected by groundwater, therefore, the isotopic value of soil water changes little.

\section{The Hydrogen-Oxygen Isotopes Characteristics of Plant Water}

Among 6 dominant shrub plants, the range of $\delta^{2} \mathrm{H}$ of plant water is $-51.75 \%$ - $-32.63 \%$, and the average value is $-43.89 \%$, and the standard deviation is 4.52 . The range of $\delta^{18} \mathrm{O}$ is $-6.33 \%$ - $4.04 \%$, and the average value is $-5.44 \%$, and the standard deviation is 0.68 . Compared with precipitation and soil water, isotope values of plant water vary less, but the average value is between them. This indicates that the plant water in study area is derived mainly from atmospheric precipitation and soil water. Because the isotope occur enrichment in the process of plant transpiration, the isotope values of plant water are higher than those of soil water.

From the comparison of the $\delta^{18} \mathrm{O}$ values in different dominant plants (Table 2), it can be known that the $\delta^{18} \mathrm{O}$ value of $R$. capitatum Maxim is the lowest (-6.06\%), and those of $S$. oritrepha Schneid, $R$. thymifolium Maxim and $P$. fruticosa Linn are relatively higher (-4.98\%o, $-5.05 \%$, $-5.01 \%$, respectively), and those of S. Salicifolia L. and S. cupularis are slightly lower $(-5.63 \%$ and $-5.34 \%$, respectively). From the perspective of standard deviation, the range of $\delta^{18} \mathrm{O}$ variation of $S$. oritrepha Schneid, $R$. capitatum Maxim and P. fruticosa Linn are relatively stable (standard deviations are $0.24,0.23$ and 0.24 , respectively), and those of $\mathrm{S}$. cupularis and $R$. thymifolium Maxim are very wider (standard deviations is 0.94 and 1.07, respectively), that of $S$. Salicifolia L. is slightly larger (standard deviation is $0.63)$. The isotope values of 6 dominant shrub plants are 
Table 2. Characteristics of $\delta^{18} \mathrm{O}$ values of different plant water.

\begin{tabular}{|c|c|c|c|c|}
\hline Species & Average value (\%) & Standard deviation (\%) & Maximum (\%) & Minimum (\%) \\
\hline S. oritrepha Schneid & -4.98 & 0.24 & -5.25 & -4.81 \\
\hline R. capitatum Maxim & -6.06 & 0.23 & -6.31 & -5.85 \\
\hline S. Salicifolia L. & -5.63 & 0.63 & -6.33 & -5.10 \\
\hline S. cupularis & -5.34 & 0.94 & -6.17 & -4.32 \\
\hline R. thymifolium Maxim & -5.05 & 1.07 & -6.16 & -4.04 \\
\hline P. fruticosa Linn. & -5.01 & 0.24 & -5.20 & -4.75 \\
\hline
\end{tabular}

different, which is not only related to their properties of transpiration, but also related to the absorption of precipitation and soil water in different depths.

\section{The Hydrogen-Oxygen Isotopes Characteristics of Groundwater}

The $\delta^{2} \mathrm{H}$ value of groundwater varies between $-56.33 \%$ and $-53.27 \%$ (arithmetic mean -54.63\%o), having the standard deviation of 0.84 . The $\delta^{18} \mathrm{O}$ value varies between $-9.32 \%$ and $-8.53 \%$ (arithmetic mean $-8.91 \%$ ), having the standard deviation of 0.21 . Compared with the isotope values of precipitation, soil water and plant water, the values of $\delta^{2} \mathrm{H}$ and $\delta^{18} \mathrm{O}$ of groundwater are smaller. It indicates that the groundwater is fractionated during its formation. The values of the isotope are low, and the variation range of them is small, which indicates that the source of groundwater is relatively stable. Although isotope values of groundwater fluctuate more slowly than those of precipitation, soil water and plant water, groundwater has a certain degree of response to intense precipitation events. Fig. 6 shows that the $\delta^{18} \mathrm{O}$ value of groundwater has three high values on July $15^{\text {th }}$, July $25^{\text {th }}$ and August $4^{\text {th }}$, respectively. Compared with the precipitation amount at the same time, three consecutive precipitation events occurred on July $12^{\text {th }} \sim 18^{\text {th }}$, July $20^{\text {th }} \sim 22^{\text {nd }}$, July $31^{\text {st }} \sim$ August $3^{\text {rd }}$, and the precipitation amount was intense and frequent. Moreover, the soil texture of study area is loose, so the precipitation infiltrates quickly into the ground through the soil, which results in an increase of isotope values of groundwater (although this response is weak). In addition, the $\delta^{18} \mathrm{O}$ value of groundwater is close to that of deep soil water $(60 \sim 80 \mathrm{~cm})$, and the changes of them with the time variation are more consistent. The linear correlation coefficient between them is 0.63 . It shows that they have commonality in the supply water source and formation process, and have the possibility of mutual transformation.

\section{The Hydrogen-Oxygen Isotopes Characteristics of River Water}

The variation of $\delta^{2} \mathrm{H}$ value of river water is $-54.99 \%$ - $49.76 \%$, and the average value is $-52.50 \%$, and the standard deviation is 1.39 . The variation of

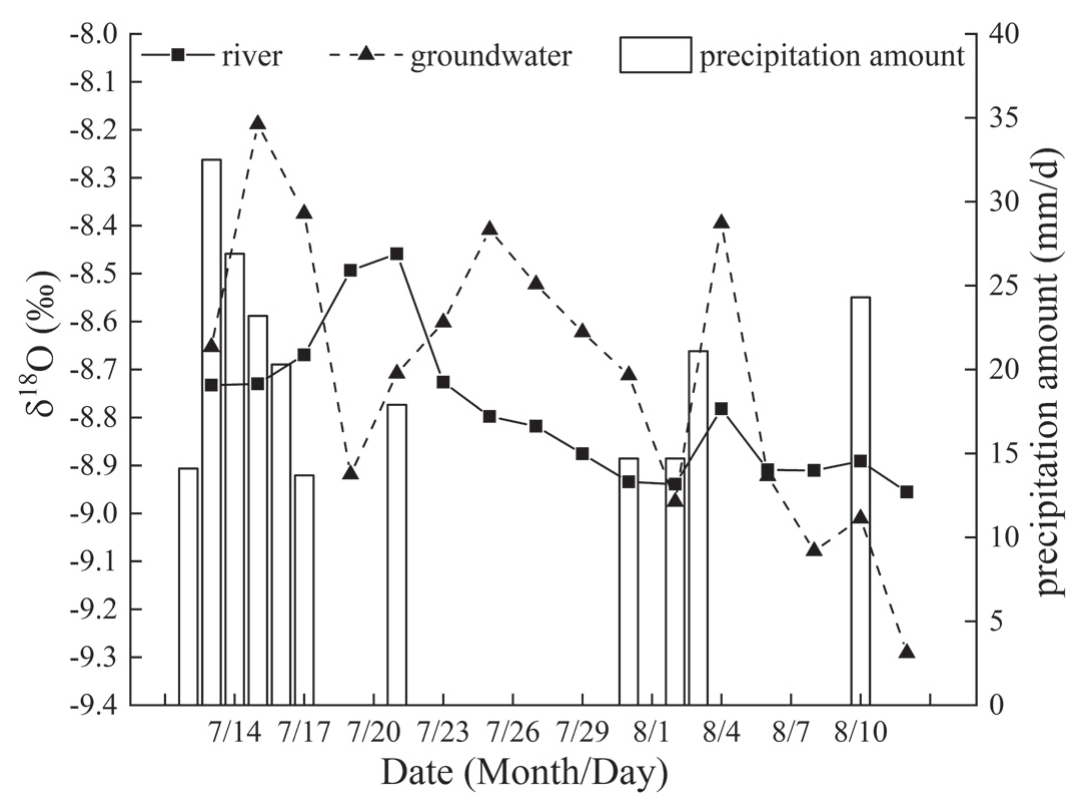

Fig. 6. Relationship between precipitation amount and $\delta^{18} \mathrm{O}$ value of river water and groundwater during sampling period. 
$\delta^{18} \mathrm{O}$ value of river water is $-8.96 \%$ - $8.46 \%$, and the average value is $-8.79 \%$, and the standard deviation is 0.15 . The average value of $\delta^{18} \mathrm{O}$ of river water in study area is negative, which is consistent with the general rule of heavy isotope depletion in rivers with highaltitude precipitation or glacial meltwater [44]. Among the five types of water bodies, the $\delta^{18} \mathrm{O}$ variation of river water is the smallest, indicating that the supply source of river water is relatively stable and less affected by precipitation. In addition, the $\delta^{18} \mathrm{O}$ values of river water, deep soil water and groundwater are close. This indicates that the supply of deep soil water and groundwater to river water accounts for a large proportion except for precipitation recharge [45].

Fig. 6 shows that the $\delta^{18} \mathrm{O}$ value of river water in the study area has a certain degree of response to precipitation events too. Rapid recharge in the process of precipitation leads to high values of water isotope. While the source of river water in the non-rainfall periods are mainly soil water or groundwater, so the isotope values of it are low. The precipitation was mainly concentrated on two periods from July $12^{\text {th }}$ to $22^{\text {nd }}$ and July $31^{\text {st }}$ to August $3^{\text {rd }}$. At the same time, the $\delta^{18} \mathrm{O}$ values of river water had two peaks on July $21^{\text {st }}$ and August $4^{\text {th }}$, respectively. However, the recharge of precipitation to river water was very limited during the dry period, because the $\delta^{18} \mathrm{O}$ value of the river water has shown a continuous downward trend from July $23^{\text {rd }}$ to July $30^{\text {th }}$, and reached the lowest value on August $2^{\text {nd }}$. In addition, the change of $\delta^{18} \mathrm{O}$ values of river water was inconsistent to those of groundwater before July $25^{\text {th }}$, but it was more consistent afterwards. This indicates that the river water responds to precipitation quickly, but the groundwater respond to precipitation slowly. This is because the recharge of precipitation to groundwater depends on the soil infiltration process, but the continuous precipitation leads to soil saturation and the weakening of infiltration capacity, which leads river water to response obviously to precipitation and leads the slope runoff to increase. In the non-rainfall season, the source of river water is mainly soil water and groundwater, so the variation range of $\delta^{18} \mathrm{O}$ values of river water is small.

\section{Discussion}

\section{Source of Precipitation Supply}

The isotope characteristics of precipitation can reflect the regional climate background, so the stable isotope of hydrogen and oxygen in precipitation can be used to reflect the information of the atmospheric water cycle and track the source of precipitation [3]. Li et al. [24] found that the precipitation moisture in the Wushaoling area of the eastern Qilian Mountains from July to August 2013 was sourced from the monsoon circulation. The precipitation in the eastern Qilian Mountains is dominated by westerly winds, and the source of water vapor is mainly continental local water vapor masses in the westerly zone $[36,44]$. The calculation of the HYSPLIT model in the study area also shows the same phenomenon (Fig. 7). According to the variation characteristics of precipitation amount from July to August, the sources of water vapor were divided into 3 time points: July $22^{\text {nd }}$, August $3^{\text {rd }}$, and August $14^{\text {th }}$ (Fig. 7). It can be clearly seen from Fig. 7 that the sources of water vapor in 3 time periods were all mainly affected by the westerly wind.

Generally, the long-distance transportation of water vapor will cause the stable isotopes of precipitation to be negative. It can be seen from Fig. 7a) that the source of precipitation on July $22^{\text {nd }}$ came from the long-distance transportation of water vapor. At the same time, the isotope values of precipitation in the period before July $22^{\text {nd }}$ showed a continuous downward trend, and they reached lower values on July $16^{\text {th }}$ and July $21^{\text {st }}$. This is related to the long-distance transportation of water

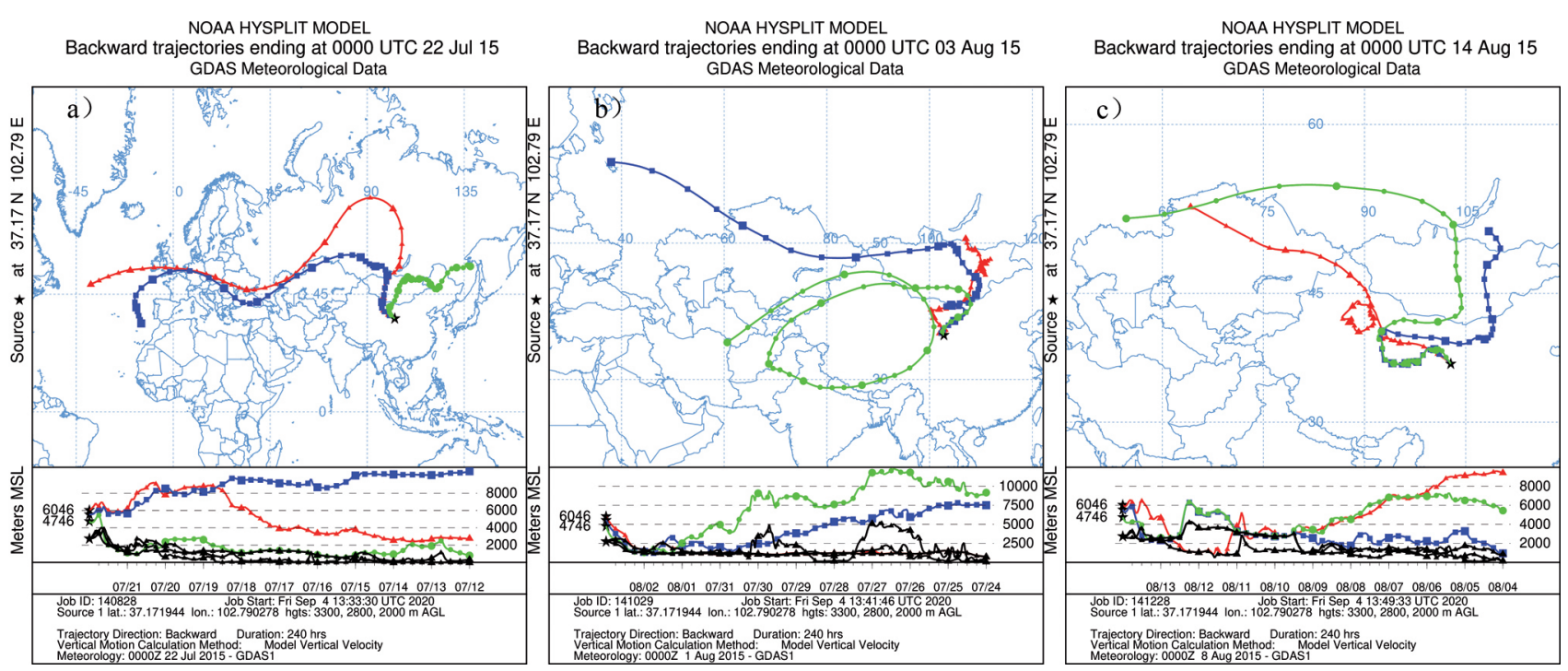

Fig. 7. Path of water vapor source of precipitation by HYSPLIT model. a) Path on July 22; b) Path on August 3; c) Path on August 14. 
Table 3. Contribution to soil water in different periods.

\begin{tabular}{|c|c|c|c|}
\hline \multirow{2}{*}{ Date } & Layer $(\mathrm{cm})$ & Precipitation contribution (\%) & Groundwater contribution (\%) \\
\hline \multirow{3}{*}{ July 23 } & Surface layer $(0 \sim 20 \mathrm{~cm})$ & 58.9 & 41.1 \\
\cline { 2 - 4 } & Middle layer $(20 \sim 60 \mathrm{~cm})$ & 37.2 & 62.8 \\
\cline { 2 - 4 } & Deep layer $(60 \sim 80 \mathrm{~cm})$ & 32.9 & 67.1 \\
\hline \multirow{3}{*}{ August 2 } & Surface layer $(0 \sim 20 \mathrm{~cm})$ & 18.5 & 81.5 \\
\cline { 2 - 4 } & Middle layer $(20 \sim 60 \mathrm{~cm})$ & 17.8 & 95.2 \\
\hline \multirow{3}{*}{ August 14} & Deep layer $(60 \sim 80 \mathrm{~cm})$ & 4.5 & 53.5 \\
\cline { 2 - 4 } & Surface layer $(0 \sim 20 \mathrm{~cm})$ & 46.5 & 68.7 \\
\cline { 2 - 4 } & Middle layer $(20 \sim 60 \mathrm{~cm})$ & 31.3 & 84.7 \\
\hline
\end{tabular}

vapor. In addition, the precipitation amount during this period is larger and precipitation events are frequent. In contrast, for a long period of time after July $22^{\text {nd }}$, as the frequency of precipitation decreases, the isotope values of precipitation increase. This is due to the enhanced evapotranspiration of water bodies and vegetation in the study area in summer, and the local recycled water vapor also has a certain contribution. In addition, the locally sub-cloud evaporation in summer and autumn cause relatively higher $\delta^{18} \mathrm{O}$ values [46].

\section{Source of Soil Water Supply}

Based on the data of hydrogen-oxygen isotope, the MixSIAR model was used to analyze the sources of soil water in the surface layer $(0 \sim 20 \mathrm{~cm})$, the middle layer $(20 \sim 60 \mathrm{~cm})$, and the deep layer $(60 \sim 80 \mathrm{~cm})$. The results are as follows (Table 3 ).

From the temporal change, the contributions of precipitation to the surface, middle and deep soil water on July $23^{\text {rd }}$ were $58.9 \%, 37.2 \%$ and $32.9 \%$ respectively, and those to soil water in different soil layers were the highest in three periods. In August, the contributions of precipitation to the surface, middle and deep soil water are quite different. On August $2^{\text {nd }}$, they were $18.5 \%, 17.8 \%$ and $4.5 \%$ respectively. On August $14^{\text {th }}$, they were $46.5 \%, 31.3 \%$, and $15.3 \%$, respectively. Both the contributions of precipitation to soil water in these two periods were less than that on July $23^{\text {rd }}$. In contrast, the contributions of groundwater to the surface, middle and deep soil water in August were higher than that on July $23^{\text {rd }}$. On August $2^{\text {nd }}$, they were $81.5 \%, 82.2 \%$, and $95.5 \%$ respectively. On August $14^{\text {th }}$, they were $53.5 \%$, $68.7 \%$, and $84.7 \%$ respectively. This is related to the decrease of frequency and amount of precipitation in August. When the precipitation amount decreases, the contribution of precipitation to soil water also decreases, but that of groundwater to soil water increases. It was most obvious on August $2^{\text {nd }}$ when the precipitation amount is the least.
From the soil profile, the contribution of precipitation to soil water during three periods all decreased with the increase of soil depth, but it is opposite to groundwater. The difference of contributions both precipitation and groundwater to soil water also increase with the increase of depth. This indicates that the surface soil is more susceptible to the direct impact of precipitation, but the recharge of precipitation to deep soil water is very limited. This is consistent with the result of isotopic characteristics of soil water in Qilian Mountain of the northwestern Qinghai-Tibet Plateau [28]. Comparing the contributions of precipitation and groundwater in three periods, it is found that the contribution of groundwater is generally higher than that of precipitation, and its change rate is relatively low. This indicates that the soil water in study area is recharged mainly by groundwater. On one hand, this is because the Wushaoling area has loose soil, high soil porosity and strong water permeability, which makes the groundwater to replenish soil moisture. On the other hand, the groundwater in study area is sufficient, and the groundwater level is relatively high, which can replenish the moisture of the deep soil. When the precipitation amount is insufficient to infiltrate into the deeper soil, the groundwater becomes the main source of soil water.

\section{Source of Plant Water Supply}

To calculating the water absorption sources of different plants, precipitation, soil water and groundwater are regarded as relatively independent water sources. The results are as follows (Fig. 8).

It can be seen that water sources of six typical shrub plants in the Qilian Mountains are mainly composed of precipitation and surface soil water. From the time point of sample, the contributions of precipitation and surface soil water to plant water in three periods reached $36.38 \%, 38.42 \%, 55.35 \%$ and $37.63 \%, 18.2 \%, 16.07 \%$ respectively. The contribution of precipitation to plant water was the largest on August $14^{\text {th }}$, but it was opposite 

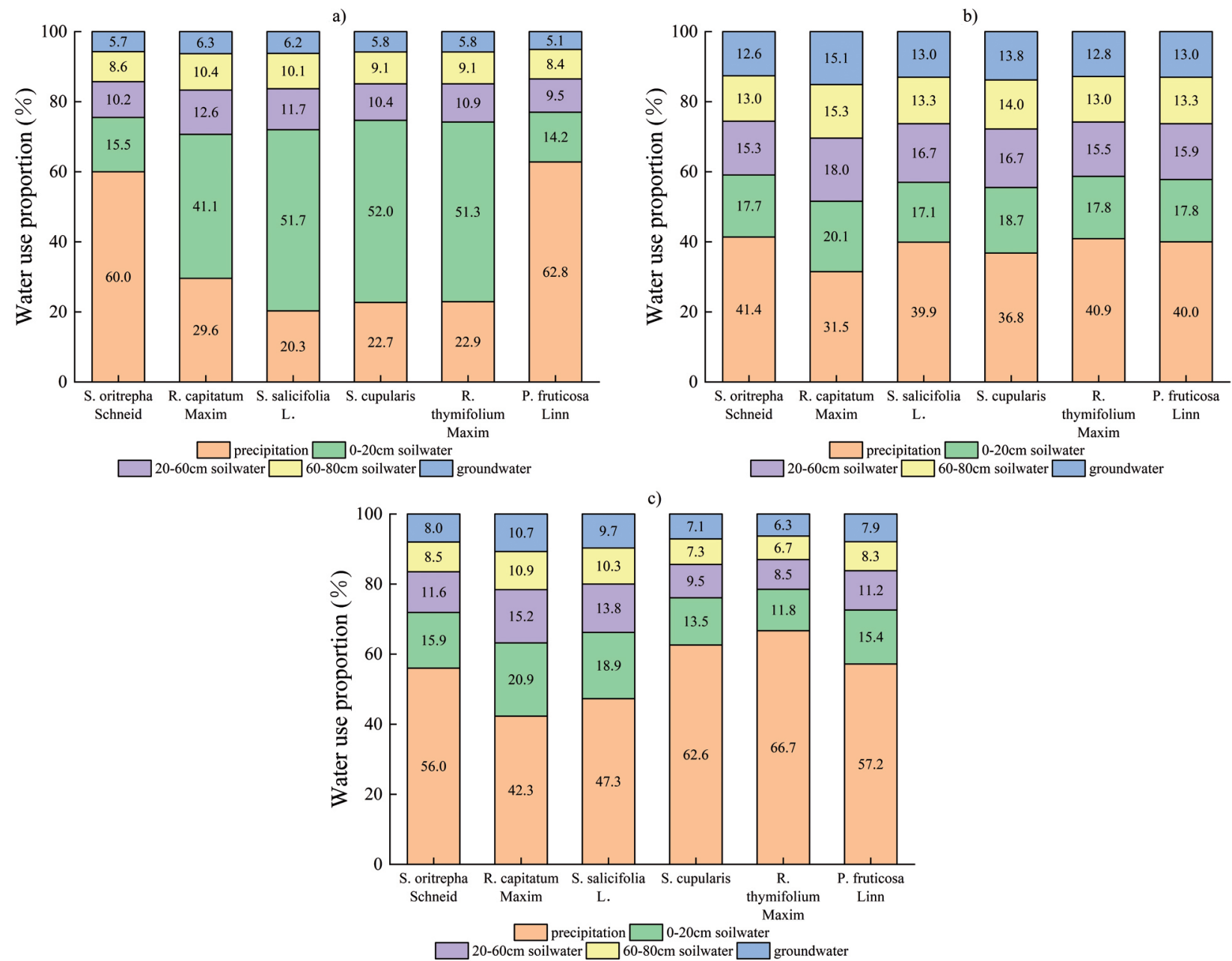

Fig. 8. Contribution to plant water in different periods. a) Contribution on July 23; b) Contribution on August 2; c) Contribution on August 14.

to the surface soil water. The contributions of middle and deep soil water and groundwater were the highest on August $2^{\text {nd }}$. This shows that the middle and deep soil water and groundwater have become a stable water source of plant during the period of rare precipitation. From the perspective of vertical section, the contribution of soil water to plants is gradually reduced with the increase of soil depth, and the contribution of groundwater is the lowest. Soil water of $0 \sim 20 \mathrm{~cm}$ provides a higher contribution to plants. This is because the temperature, water content and permeability are lower in the soil layer below $20 \mathrm{~cm}$, which results that the roots of shrub plant are shallow and underground biomass reduce. This also demonstrates the adaptability of the root water absorption depth of alpine shrub to the environment of alpine regions [47].

Among the underground root system of plant, although the proportion of fine roots (diameter $\leq 1 \mathrm{~mm}$ ) is not high, they play an important role in the cycle of absorbing water and minerals, synthesizing and storing nutrients, and interacting with soil microorganisms [48]. The proportion of fine roots affects directly the physiological functions of roots and the ability to utilize soil resources [49]. Compared to soil water and groundwater, precipitation has the highest contribution to $P$. fruticosa Linn, reaching $53.33 \%$. Zhou et al. [50] found that the roots of $P$. fruticosa Linn shrubs are long-distance horizontal distribution and large distribution scope, and that the underground biomass of soil layer of $0 \sim 10 \mathrm{~cm}$ accounts for $74.53 \%$ of the total biomass while that of the soil layer below $20 \mathrm{~cm}$ only accounts for $10.13 \%$. Therefore, $P$. fruticosa Linn has the stronger ability of water absorption for precipitation. Zhang et al. [51] found that the main root of $R$. capitatum Maxim is not obvious, and that the fine roots have many branches, and that the roots are small and dense. Qiu et al. [52] found that central root $(5 \sim 10 \mathrm{~mm})$, small root $(2 \sim 5 \mathrm{~mm})$ and fine root $(<2 \mathrm{~mm})$ of S. Salicifolia L. play an important role in water and nutrient absorption, and that they have strong adaptability in stressful habitats. In this study, the proportion of middle and deep soil water and groundwater to $R$. capitatum Maxim and $S$. Salicifolia L. was higher. The overall contribution of middle and deep soil water reached $27.47 \%$ and $25.30 \%$ respectively, and the contribution of groundwater reached $10.70 \%$ and $9.63 \%$, respectively. It shows that 
Table 4. Contribution to groundwater in different periods.

\begin{tabular}{|c|c|c|c|}
\hline Date & $\begin{array}{c}\text { Precipitation } \\
\text { contribution } \\
(\%)\end{array}$ & $\begin{array}{c}\text { Soil water } \\
\text { contribution } \\
(\%)\end{array}$ & $\begin{array}{c}\text { Precipitation } \\
\text { amount } \\
(\mathrm{mm})\end{array}$ \\
\hline July 23 & 92.4 & 7.6 & 148.6 \\
\hline August 2 & 12.2 & 87.8 & 29.4 \\
\hline August 14 & 36.9 & 63.1 & 45.4 \\
\hline
\end{tabular}

Note: "Precipitation amount (mm)" is the weighted cumulative value of daily precipitation amount.

R. capitatum Maxim and S. Salicifolia L. have the most adequate absorption and utilization to medium and deep soil water and groundwater. This is also consistent with the conclusion provided by Ding et al. [53]. Cao et al. [54] found that $R$. thymifolium Maxim has a shallow root system, and that $90 \%$ of biomass of the underground fine root is distributed in shallow soil of $0 \sim 20 \mathrm{~cm}$, and that the biomass of living root shows a decreasing law with the increase of soil depth. This is consistent with the results of this study. For example, the contribution of soil water of $0 \sim 20 \mathrm{~cm}$ to $R$. thymifolium Maxim reaches to $26.97 \%$, and those of $20 \sim 60 \mathrm{~cm}$ and $60 \sim 80 \mathrm{~cm}$ decrease to $11.63 \%$ and $9.60 \%$ respectively. The main roots of $S$. oritrepha Schneid and S. cupularis are relatively thin and the lateral roots are more developed. Xu et al. [55] pointed out that S. cupularis has a deep root distribution but has a small range of root width distribution. In this study, it is found that $S$. cupularis has a higher utilization rate for soil water of $0 \sim 80 \mathrm{~cm}$ than $S$. oritrepha Schneid.

\section{Source of Groundwater Supply}

The groundwater level in the study area is relatively high, and the hydrogen-oxygen isotope ratio of groundwater is relatively stable after comparison with other water bodies. The results of calculating the contributions of water source of groundwater by the MixSIAR model are as follows (Table 4).

With the change of time, the recharge of precipitation to groundwater decreases firstly and then increases, while this is opposite for the recharge of soil water to groundwater. This is closely related to the trend of precipitation amount. On July $23^{\text {rd }}$, the recharge of precipitation to groundwater was $92.4 \%$, but that was only $12.2 \%$ on August $2^{\text {nd }}$. This is because the reduction of precipitation during the period affects the recharge of groundwater. Subsequently, due to the continuous precipitation events from August $8^{\text {th }}$ to $10^{\text {th }}$, the contribution of precipitation to groundwater increased to $36.9 \%$ on August $14^{\text {th }}$. The recharge of precipitation to groundwater passes mainly through the method of infiltration. Since the precipitation cannot infiltrate into the deep soil during the period of less precipitation amount, the soil water of early stage plays an important role in the recharge of groundwater. The contributions
Table 5. Contribution to river water in different periods.

\begin{tabular}{|c|c|c|c|}
\hline Date & $\begin{array}{c}\text { Precipitation } \\
\text { contribution } \\
(\%)\end{array}$ & $\begin{array}{c}\text { Soil water } \\
\text { contribution } \\
(\%)\end{array}$ & $\begin{array}{c}\text { Groundwater } \\
\text { contribution } \\
(\%)\end{array}$ \\
\hline July 23 & 3.9 & 8.9 & 87.2 \\
\hline August 2 & 3.5 & 21.3 & 75.2 \\
\hline August 14 & 6.1 & 20.2 & 73.7 \\
\hline
\end{tabular}

of precipitation and soil water to groundwater are related to changes of precipitation amount. Due to strong rainfall in July, the precipitation replenishes effectively groundwater. In addition, groundwater replenishes middle and deep soil water with a large proportion during periods of less precipitation amount. In contrast, soil water replenishes groundwater significantly during periods of abundant rainfall. This is due to the combination of higher groundwater level and higher soil permeability in the study area. Affected by changes of precipitation amount, there is no single directional replenishment method between middle and deep soil water and groundwater.

\section{Source of River Water Supply}

The oxygen isotope ratio of river water in study area is the lowest, which is the most stable among the 5 types of water bodies. The calculation results of the water source of river water are as follows (Table 5).

The calculation results show that groundwater is the main recharge source of river water, followed by soil water, and the contribution of precipitation is the lowest. This result not only verifies that the fluctuations of isotope value of river water are small, but also shows that there is a close relationship between groundwater and river water. During the sampling period, the contribution of precipitation to river water decreases firstly and then increases, while this is opposite to soil water. On July $23^{\text {rd }}$, the contributions of groundwater, soil water and precipitation to river water reached $87.2 \%, 8.9 \%$ and $3.9 \%$ respectively. Although the rainfall is frequent and intense before the day, the recharge source of river water is mainly from groundwater. The contribution of groundwater to river water in August also reached more than 70\%. Compared with July, the frequency and amount of precipitation decreases significantly in August. The contribution of precipitation to river water varies with precipitation amount, but its direct contribution is only $3.5 \% \sim 6.1 \%$. This is because the loose soil, high porosity and strong water permeability of the study area causes the surface runoff ability of rainfall to decrease. Therefore, the unstable water source of precipitation to the supply of river water is not obvious. The main supply source of river water is relatively stable groundwater. The higher contribution of groundwater to river water is related to the groundwater level which is higher than the river 
level, and may be related to the high plant coverage in study area. It is a period of strong growth of subalpine shrubs from July to August. The plant can retain a large amount of precipitation and infiltrate to form groundwater. Therefore, the contribution of groundwater to river water is relatively high. This is consistent with the result of the recharge source of river water at the alpine shrub zone of the Hulugou small watershed in the upper reaches of the Heihe River [42].

\section{Transformation Relationship between Different Water Bodies}

The transformation between different water bodies in the subalpine zone of Qilian Mountains is intricate and there is no single directional supply method [56]. Through above qualitative and quantitative analysis of the recharge relationship and the contribution ratio between various water bodies, the ecological hydrological process of the study area can be roughly restored. The precipitation is mainly affected by the westerly circulation in summer, and affected by the local sub-cloud evaporation at the same time. During periods of abundant precipitation, precipitation can replenish groundwater through the soil infiltration, although the replenishing proportion of precipitation to groundwater is relatively small. There is twoway water transport between middle and deep soil water and groundwater. During periods of scarce precipitation, groundwater can replenish middle and deep soil water in a certain amount. While during periods of abundant precipitation, middle and deep soil water can replenish a large amount of groundwater. Since the root systems of subalpine shrubs are mainly concentrated on soil layer of $0-20 \mathrm{~cm}$, the plants mainly absorb surface soil water and precipitation. The river water in study area is mainly supplied by groundwater and soil water. However, this study mainly discusses hydrogen and oxygen isotope characteristics of various water bodies and the recharge sources of them in summer in subalpine shrub area of Qilian Mountains. The study of long-term series and larger-scale water replenishment of various water bodies is future research focus. Next, more work about ecological hydrological process in subalpine shrub area of Qilian Mountains will be done.

\section{Conclusions}

The isotope values of precipitation from July to August in the sub-alpine region of the Qilian Mountains are relatively high, and its fluctuation ranges are relatively large. The linear correlation between $\delta^{18} \mathrm{O}$ and precipitation amount $(\mathrm{P})$ is: $\delta^{18} \mathrm{O}=-0.0985 \mathrm{P}-1.8021$ $\left(\mathrm{R}^{2}=-0.2568, \mathrm{n}=11\right)$, and there is a significant precipitation amount effect. The water vapor source of precipitation is affected by the double influence of westerly circulation and the local sub-cloud evaporation.

With the increase of soil depth, the contribution of precipitation to soil water decrease, but this is opposite to groundwater. Soil water of $0 \sim 20 \mathrm{~cm}$ is affected most easily by precipitation and evaporation, and the isotope values are relatively high and its variation ranges are relatively large. Soil water of $60 \sim 80 \mathrm{~cm}$ is affected strongly by groundwater, and the isotope values are relatively low and its variation ranges are relatively stable.

The root of shrub plant in the subalpine area of Qilian Mountains is mainly concentrated on the soil layer of $0 \sim 20 \mathrm{~cm}$, and the water content of it is mainly derived from precipitation and surface soil water. $P$. fruticosa Linn has a shallower root distribution, and the replenishment of precipitation to plant water has a higher proportion. $R$. capitatum Maxim and $S$. Salicifolia L. have higher water absorption efficiency in deep soil.

The variation range of $\delta^{2} \mathrm{H}$ and $\delta^{18} \mathrm{O}$ of groundwater and river water are relatively small, and the isotopes values of them are also lower than other types of water bodies. Both groundwater and river water have different degrees of response to precipitation amount. The river water responds to precipitation amount faster than groundwater.

There are close hydraulic connections between precipitation with surface water, as well as between groundwater and middle and deep soil water. There are good conditions of soil permeability and runoff connectivity in subalpine shrub area of Qilian Mountains, the eco-hydrological process of various water bodies is complicated. The study of long-term series and larger-scale water replenishment of various water bodies is future research focus.

\section{Acknowledgements}

We thank our team for their valuable assistance. This research was supported by National Natural Science Foundation of China (41661005, 41867030, 41971036), National Natural Science Foundation innovation research group science foundation of China (41421061), and Autonomous project of State Key Laboratory of Cryosphere Sciences (SKLCS-ZZ-2017).

\section{Conflict of Interest}

The authors declare no conflict of interest.

\section{References}

1. DING Y.J., ZHANG S.Q. Study on water internal recycle process and mechanism in typical mountain areas of inland basins, northwest China: Progress and challenge. Advances in Earth Science. 33 (07), 719, 2018. 
2. ZHU G.F., GUO H.W., QIN D.H., PAN H.X., ZHANG Y., JIA W.X., MA X.G. Contribution of recycled moisture to precipitation in the monsoon marginal zone: estimate based on stable isotope data. Journal of Hydrology. 569, 423-435, 2018.

3. GU W.Z. Isotope Hydrology. Science Press: Beijing, China. 154, 2011.

4. PAUL K., CHRISTIAN L., TIMOTHY L., JOHN D.M. Stable isotopes applied as water tracers in column and field studies. Organic Geochemistry. 41, 31, 2010.

5. HE Y.Q., PANG H.X., THEAKSTONE W.H., ZHANG Z.L., LU A.G., GU J. Isotopic variations in precipitation at Bangkok and theirc limatological significance. Hydrology Process. 20, 2873, 2006.

6. XU Y.D., WANG J.K., GAO X.D., ZHANG Y.L. Application of Hydrogen and Oxygen Stable Isotope Techniques on Soil Water Reaearch: A Review. Journal of Soil and Water Conservation. 32 (03), 1-9+15, 2018.

7. ZHANG X., XIAO Y., WAN H., DENG Z.M., PAN G.Y., XIA, J. Using stable hydrogen and oxygen isotopes to study water movement in soil-plant-atmosphere continuum at Poyang Lake wetland, China. Wetlands Ecol Manage. 25, 221, 2017.

8. ANDREA D., BRUCE H. Spatial distribution and seasonal variation in ${ }^{18} \mathrm{O} /{ }^{16} \mathrm{O}$ of modern precipitation and riverwater across the conterminous USA. Hydrology Process. 19, $4121,2005$.

9. ZHAO M., HU Y.D., ZENG C., LIU Z.H., YANG R., CHEN B. Effects of land cover on variations in stable hydrogen and oxygen isotopes in karst groundwater:A comparative study of three karst catchments in Guizhou Province, Southwest China. Journal of Hydrology. 565, 2018.

10. KEIRITH A.S., DAVID G.W. Water sources used by riparian trees varies among stream types on the San Pedro River, Arizona. Agricultural and Forest Meteorology. 105 (1), 2000.

11. PHILLIPS D.L., GREGG J.W. Source partitioning using stable isotopes:coping with too many sources. Oecologia. 136 (2), 261, 2003.

12. MOORE J.W., SEMMENS B.X. Incorporating uncertainty and prior information into stable isotope mixing models. Ecology Letters. 11 (5), 470, 2008.

13. PARNELL A.C., INGER R., BEARHOP S., JACKSON A.L. Source partitioning using stable isotopes: coping with too much variation. PLoS One. 5 (3), e9672, 2010.

14. STOCK B.C., SEMMENS B.X. Mix SIAR GUI User Manual, version 1.0. http://conserver.iugo-cafe.org/user/ brice.semmens/Mix SIAR. 2013.

15. MA Y., SONG X.F. Using stable isotopes to determine seasonal variations in water uptake of summer maize under different fertilization treatments. Science of the Total Environment. 550, 471, 2016.

16. DU J.S., MA Y., HU X.N., TONG J.X., ZHANG B.Z., SUN N.X., GAO G.Y. Applying dual stable isotopes and a MixSIAR model to determine root water uptake of winter wheat. Acta Ecologica Sinica. 38 (18), 6611, 2018.

17. LIU K.Y., SI B.C., ZHANG Z.Q. Responses of Water Uptake Pattern of Apple Trees with Different Stand Agesto Precipitation on the Loess Plateau. Journal of Soil and Water Conservation. 32 (04), 88-94+108, 2018

18. WANG L. The Source Apportionment of Groundwater Nitrate Nitrogen pollution. China University of Geosciences (Beijing). 2016.

19. ZHANG Y., ZHANG Q.Y., LI F.D., ZHANG X., BI Z.L.,
ZHANG Q. Source identification of nitrate contamination of groundwater in Yellow River Irrigation Districts using stable isotopes and Bayesian model. Chinese Journal of Eco-Agriculture. 27 (3), 484, 2019.

20. LI Z.X., FENG Q., LI Z.J., LV Y.M., YUAN R.F., GUI J., LI Y.G., ZHANG B.J., XUE J. Preliminary progress of ecohydrology based on stable isotope tracing in the northern Qilian Mountains and its applications. Journal of Glaciology and Geocryology. 41 (5), 2019.

21. CHE K.J., FU H.E. Investigation on Forest, Glacier and Water Resources in the Qilian Mountains. Journal of Beijing Forestry University. 06, 99, 1998.

22. WANG J.Y., WANG Y.H., WANG S.L., YU P.T., ZHANG X.L., GE S.L. A Preliminary Study on the Precipitation Variation of Complex Watershed on Forestry and Grasses of Qilian Mountains. Forest Research. 04, 416, 2006.

23. YANG Q.C., MU H.K., WANG H., YE X.Y., MA H.Y., MARTIN J.D. Quantitative evaluation of groundwater recharge and evaporation intensity with stable oxygen and hydrogen isotopes in a semi- arid region, Northwest China. Hydrological Processes. 32 (9), 2018.

24. LI Z.X., FENG Q., YONG S., WANG Q.J., JIAO Y., LI Y.G., LI J.G., GUO X.Y. Stable isotope composition of precipitation in the south and north slopes of Wushaoling Mountain, northwestern China. Atmospheric Research. 182, 87, 2016.

25. FENG F., FENG Q., LIU X.D., WU J.K., LIU W. Stable isotopes in precipitation and atmospheric moisture of Pailugou Catchment in northwestern China's Qilian Mountains Chinese. Geographical Science. 27, 97, 2017.

26. GUO X.Y., FENG Q., LIU W., LI Z.X., WEN X.H., SI J.H., XI H.Y., GUO R., JIA B. Stable isotopic and geochemical identification of groundwater evolution and recharge sources in the arid Shule River Basin of Northwestern China. Hydrological Processes. 29 (22), 2015.

27. MA J.Z., ZHANG P., ZHU G.F,, WANG Y.Q., MIKE E.W., DING Z.Y., HE J.H. The composition and distribution of chemicals and isotopes in precipitation in the Shiyang River system, northwestern China. Journal of Hydrology. 436-437, 2012.

28. QIU X., ZHANG M.J., WANG S.J. Preliminary research on hydrogen and oxygen stable isotope characteristics of different water bodies in the Qilian Mountains, northwestern Tibetan Plateau. Environmental Earth Sciences. 75, 1491, 2016.

29. ZHAO L.J., YIN L., XIAO H.L., CHENG G.D., ZHOU M.X., YANG Y.G., LI C.Z., ZHOU J. Isotopic evidence for the moisture origin and composition of surface runoff in the headwaters of the Heihe river basin. Chinese Science Bulletin. 56 (4), 406, 2011.

30. TENG S.C., ZHANG M., TENG J., QIAO Q. Climatic Change Characteristics in Wushaoling Region of Gansu Province During 1951-2016. Journal of Arid Meteorology. 36 (1), 75-81+129, 2018.

31. ZENG B., ZHANG F.G., YANG T.B., QI J.G., GHEBREZGABHER, M.G. Alpine sparsely vegetated areas in the eastern Qilian Mountains shrank with climate warming in the past 30 years. Progress in Physical Geography. 42 (4), 2018.

32. GAO W.H., GAO W.Y. Comprehensive Drought-Resistant Afforestation Technology in Wushaoling Forest Region in Eastern Qilian Mountains. Soil and Water Conservation in China. 08, 60-61+69, 2019.

33. JIA W.X, WANG J., ZHANG Y.S., LIU Y.R. Biomass Variation of Shrubbery Meadow and Relation with Humidity and Heat Facts in the Southren Slop of the 
Qilian Mountains. Scientia Geographica Sinica. 36 (8), 1243, 2016.

34. LIU W.R. Analyse of stable Hydrogen and Oxygen isotopes on extraction and measurement methods and evaluation of water sources of peanut. Nanjing Agricultural University. 2013.

35. ZIMMERMANN M.W., GARTENBACH K.E., KRANZ A.R., BAICAN B., SCHOPPER E., HEILMANN C., REITZ G. Recent results of comparative radiobiological experiments with short and long termexpositions of Arabidopsis seed embryos. Adv. Space Res. 18 (12), 205, 1996.

36. XU X.T., JIA W.X., ZHU G.F., MA X.G., ZHANG Y., YUAN R.F., ZHANG Z.Y., SHI Y. Stable Isotope Characteristics and Vapor Source of Precipitation in the South and North Slopes of Wushaoling Mountain. Environmental Science. 41 (01), 155, 2020.

37. XU S.G., LIU Y.F., SUN W.G. Research on the Stable Isotope for Soil Water Vertical Transporting in Unsaturated zone of Zhalong Wetland. Journal of China Hydrology. (05), 1, 2006.

38. ZHENG S.H., HOU F.G., NI B.L. Study on nitrogen and oxygen stable isotope of precipitation in China. Chinese Science Bulletin. 13, 801, 1983.

39. YURTSEVER Y. Worldwide survey of stable isotope in precipitation. Vienna: IAEA, 1975.

40. YANG Q.C., MU H.K., GUO J.C., BAO X.H., MARTIN J.D. Temperature and rainfall amount effects on hydrogen and oxygen stable isotope in precipitation. Quaternary International. 519, 2019.

41. YU W.S., YAO T.D., TIAN L.D., WANG Y., SUN W.Z. Variation of $\delta 18 \mathrm{O}$ in Precipitation in the Western Tibetan Plateau. Journal of Glaciology and Geocryology. 02, 146, 2004.

42. LIU Y.G. Using hydrochemical and isotope tracers analying to delineate hydrologic process in cold alpine watershed in rainy season. China University of Geosciences. 2013.

43. WANG Y.S., XU Z.H. Analysis of Water Movement through an Unsaturated Soil Zone in Jinan Southern Mountain Using Stable Oxygen and Hydrogen Isotopes. Applied Mechanics and Materials. 3013, 2014.

44. LI Z.X., GUI J., WANG X.F., FENG Q., ZHAO T.T.G., OUYANG C.J., GUO X.Y., ZHANG B.J., SHI Y. Water resources in inland regions of central Asia: Evidence from stable isotope tracing. Journal of Hydrology. 570, 1, 2019.

45. ZIMMERMANN U., ENHALT D., MUNNICH K.O. Soilwater move-ment and evapotranspiration: changes in the isotopic composi-tion of the water. Isotopes in Hydrology, Vienna, IAEA. 567, 1967.
46. LI Z.X., GAO Y., WANG Y.M., PAN Y.H., LI J.G., CHEN A.F., WANG T.T., HAN C.T., SONG Y.X., THEAKSTONE W.H. Can monsoon moisture arrive in the Qilian Mountains in summer?. Quaternary International. 358, 113, 2015.

47. WANG Q.J., ZHOU X.M., ZHANG Y.Q., ZHAO X.Q. Structural characteristics and biomass of Potentilla Fruticosa shrub in Qinghai-Xizang plateau. Acta Botanica Boreali-occidentalia Sinica. 04, 333, 1991.

48. MCCORMACK M.L., DICKIE I.A., EISSENSTAT D.M., FAHEY T.J., FERNANDEZ C.W., GUO D.L., HELMISAARI H., HOBBIE E.A., IVERSEN C.M., JACKSON R.B., LEOOALAMMI K.J., NORBY R.J., PHILLIPS R.P., PREGITZER K.S., PRITCHARD S.G., REWALD B., ZADWORNY M. Redefining fine roots improves understanding of below-ground contributions to terrestrial biosphere processes. The New phytologist. 207 (3), 505, 2015.

49. LEPPALAMMI K.J., ARO L., SALEMAA M., HANSSON K., KLEJA D.B., HELMISAARI H.S. Fine root longevity and carbon input into soil from below- and aboveground litter in climatically contrasting forests. Forest Ecology and Management. 326, 79, 2014.

50. ZHOU H.K., ZHOU L., ZHAO X.Q., SHEN Z.X., LI Y.N., ZHOU X.M., YAN Z.L., LIU W. Study of formation pattern of below-ground biomass in Potentilla fruticosa shrub. Acta Pratacultural Science. 02, 59, 2002.

51. ZHANG D.G., CAO W.X., PU X.P., HU Z.Z. Botanical Morpha and Ecological Adaptation of Rhododendron in Eastern Qilian Mountains. Grassland and Turf. 01, 2730+37, 2003.

52. QIU Y., CHANG S.L., ZHANG Y.T., WANG W.D., HE P., WANG H.J., XIE J. Biomass estimation modeling and adaptability analysis of organ allocation in six common shrub species in Tianshan Mountains forests, China. Acta Ecologica Sinica. 35 (23), 7842, 2015.

53. DING D., JIA W.X., MA X.G., WANG J. Water source of dominant plants of the subalpine shrubland in the Qilian Mountains, China. Acta Ecologica Sinica. 38 (4), 1348, 2018.

54. CAO W.X., LI W. Spatio-temporal trends for fine root biomass of alpine Rhododendron thymifolium and their significance for ecological adaptation in Qilian Mountains. Acta Prataculturae Sinica. 25 (07), 52, 2016.

55. XU W.B., ZHAO M., WALEAT., SHI Y., HU T.H., YU Y.W. Quantitative traits, age structure and self-thining rule of three shrubs on northest edge of Qinghai-Tibet plateau. Pratacultural Science. 36 (5), 1207, 2019.

56. SAITO T. Runoff characteristics in a small mountain basin analyzed by the use of hydrogen and oxygen stable isotopes. Limnology. 1, 217, 2000. 
